\title{
Peningkatan Prestasi Belajar Siswa Pada Mata Pelajaran Al -Qur'an Hadits Melalui Model Menulis Puisi Pada Siswa Kelas V MI Bustanul Athfal Desa Pojok Kecamatan Garum Kabupaten Blitar
}

\author{
Mustorikoh, ${ }^{1}$ Bustanul Arifin ${ }^{2}$ \\ ${ }^{1}$ Pascasarjana Institut Agama Islam Tribakti Kediri, ${ }^{2}$ Institut Agama Islam Tribakti Kediri \\ 1mustorikohmiba01@gmail.com, 2arifin.bustan65@gmail.com
}

\begin{abstract}
This study aims to improve student learning achievement in the subject of the Qur'an Hadith at MI Bustanul Athfal Pojok District of Garum, Blitar Regency in the academic year 2019/2020 with realistic models and poetry media. The form of this research is Classroom Action Research (CAR) conducted in two cycles. Each cycle consists of four phases: planning, implementation, observation, and reflection. The subjects of the study were fifth-grade students of MI Bustanul Athfal Pojok, Garum sub-district, Blitar district, totalling 19 students consisting of 8 male students and 11 female students. Data sources come from teachers and students. Data collection techniques used were interviews, observation, tests, and documentation. The results of the study carried out the initial conditions before student learning increased only reached mastery of 8 students $(42.1 \%)$, while 11 students $(57.89 \%)$ had not yet reached accuracy with an average value of 65 . In the first cycle, a realistic model and media of poetry were implemented increasing student learning outcomes reached the completeness limit of 8 students $(42.1 \%)$, while 11 students $(57.89 \%)$ had not reached accuracy with an average value of 69.86 . At this stage, the second cycle of 19 students who achieved mastery of 18 students $(94.73 \%)$ who had not completed 1 student $(5.26 \%)$ and the average value of KKM science subjects was 74.79. Judging from the improvement cycle I and cycle II can conclude that this research was successful and does not need to continue the next cycle.
\end{abstract}

Keywords: Realistic Learning Model, Media Poetry, Al-Qur'an and Hadist

\begin{abstract}
Abstrak
Penelitian ini bertujuan untuk meningkatkan prestasi belajar siswa dalam mata pelajaran Qur'an Hadist di MI Bustanul Athfal Pojok Kecamatan Garum Kabupaten Blitar tahun ajaran 2019/2020 dengan model realistic dan media puisi. Bentuk penelitian ini adalah Penelitian tindakan kelas (PTK) dilakukan dalam dua siklus. Setiap siklus terdiri dari empat fase: perencanaan, implementasi, observasi, dan refleksi. Subjek penelitian adalah siswa kelas lima siswa MI Bustanul Athfal Pojok Kecamatan Garum kabupaten Blitar , berjumlah 19 siswa yang terdiri dari 8 siswa laki-laki dan 11 siswa
\end{abstract}


perempuan. Sumber data berasal dari guru dan siswa. Teknik pengumpulan data yang digunakan adalah wawancara, observasi, tes, dan dokumentasi. Hasil penelitian dilakukan kondisi awal sebelum pembelajaran siswa peningkatan hanya mencapai penguasaan 8 siswa $(42,1 \%)$, sedangkan 11 siswa $(57,89 \%)$ belum mencapai ketelitian dengan nilai rata-rata 65 . Pada siklus pertama telah dilaksanakan Model realistik dan media puisi meningkatkan hasil belajar siswa itu mencapai batas kelengkapan 8 siswa $(42,1 \%)$, sedangkan 11 siswa $(57,89 \%)$ belum mencapai ketelitian dengan nilai rata-rata 69,86. Pada tahap ini siklus kedua dari 19 siswa yang mencapai penguasaan 18 siswa (94,73\%) yang belum menyelesaikan 1 siswa $(5,26 \%)$ dan nilai rata-rata mata pelajaran sains KKM adalah 74,79. Dilihat dari siklus perbaikan I dan siklus II bisa menyimpulkan bahwa penelitian ini berhasil dan tidak perlu melanjutkan siklus berikutnya.

\section{Kata Kunci: Model Pembelajaran Realistik, Media Puisi, Al Qur'an Hadist}

\section{Pendahuluan}

Banyaknya anak-anak kesulitan dalam menghafalkan surat-surat pendek dan memahami artinya, dalam pelajaran Al Qur'an Hadits berdampak pada nilai siswa yang menurun. Maka perlu terobosan baru baik model pembelajaran atau metode yang dapat membuat anak mudah menghafal dan memahami pelajaran yang akan berdampak pada naiknya prestasi siswa.

Dalam Kurikulum 13 (K13) berdasarkan Standar Isi Madrasah Ibtidaiyah Tahun 2013 jenjang MI, sesuai jenjang fokus penelitian, kompetensi dasar yang disajikan sebagai berikut (1) memahami surat Al Kafirun, Al Ma'un dan At Takasur (2) memahami hukum mim sukun, (3) hadist tentang menyayangi anak yatim, (4) memahami Surat Al Qodar (5) membaca dan menghafal Surat Al-Alaq, (6) memahami

1 BSNP Kemdiknas. Model Silabus dan Rencana Pelaksanaan Pembelajaran Mata Pelajaran hukum bacaan waqaf dan washal, (7) mengenal Allah melalui kalimat ta' awutz, (8 hadist tentang cirri-ciri orang munafiq. Karakteristik pembelajaran mata pelajaran Al Qur'an Hadits menggunakan pendekatan yang sesuai dengan hakikat dan fungsinya. Pembelajaran dilakukan dengan pendekatan komunikatif yang menekankan aspek kinerja atau keterampilan berbahasa dan fungsi bahasa. Sementara itu, pembelajaran Al Qur'an Haditst di sekolah menggunakan pendekatan apresiatif yang menekankan apresiasi pengembangan karakter bangsa yang berbudi pekerti luhur akhlak mulia. ${ }^{1}$

Secara khusus, menulis puisi Islami anak-anak hadir melalui kompetensi pantun dan menulis kreatif puisi. Puisi anak adalah puisi yang berisi kegembiraan dan rima, mengutamakan bunyi bahasa serta membangkitkan

Bahasa Indonesia SD/MI. (Jakarta: Kemdiknas. 2010) h.1 
semangat bermain bahasa. Tema merupakan ide yang mendasari terwujudnya sebuah puisi. Puisi Islami ini sebagai media membina Al Qur'an Haditst karakter berbudi pekerti luhur akhlak mulia anak kelas V MI Bustanul Athfal Desa Pojok Kecamatan Garum Kabupaten Blitar ini mengacu pada pembelajaran Al Qur'an Haditst yang bersumber pada buku teks Membina AlQur'an Hadits pengembangan Karakter Bangsa. Dengan puisi sebagai media pembelajaran yang mengacu pada teks dalam materi buku sumber pembelajaran Al Qur'an Hadits yang dimiliki anak, mereka akan terpacu untuk membaca, selanjutnya menulis, yang secara otomatis anak sudah diajak untuk berperan aktif kreatif meningkatkan diri dalam belajarnya.

Kompetensi yang menjadi dasar penelitian ini adalah meningkatkan semangat belajar mata pelajaran $\mathrm{Al}$ Qur'an Hadits pada siswa MI Bustanul Athfal kelas $\mathrm{V}$ melalui kegiatan menulis puisi yang bersumber pada isi materi ajar "Al Al Qur'an Hadits" K13, berdasarkan Standar Isi MI Tahun 2013, dan disesuaikan dengan rencana pembelajaran yang telah dirancang. Hal ini dilandasi oleh alasan (1) puisi anak merupakan puisi kegembiraan, (2) membangkitkan semangat bermain bahasa, (3) upaya memperbaiki ketajaman visual dan kesegaran kata yang dipergunakan, mengembangkan imajinasi, dan melihat kata-kata baru

2 R.Gebhardt, D. Rodrigues. Writing: Processes and Intention. (Lexington: D Heath and Company. 1989) h.70 dalam cara baru, (4) memperkenalkan tindakan belajar, (5) ditulis berdasarkan sumber belajar yang jelas, (6) berbentuk informasi sederhana yang membuat anak dapat menafsir dan menangkap sesuatu dari wacana teks, (7) tema mengacu pada sub materi pembelajaran akidah dan akhlak, (8) sesuai dengan lingkungan anak dan kelompok anak dalam perkembangan pembelajarannya.

Mengacu pada Gebhardt \& Rodrigues ${ }^{2}$, kegiatan menulis merupakan kegiatan membelajarkan siswa untuk menggunakan otak dan indera bekerja bersama-sama. Mereka juga berpendapat bahwa menulis puisi adalah kegiatan memaknai pengalaman dan kepekaan yang dirasakan dan dilihat yang dikembangkan bersama imajinasi dengan memperhatikan unsur-unsur pembangun puisi. Aminuddin mendefinisikan puisi dengan "membuat" dan "pembuatan" karena lewat puisi pada dasarnya seseorang itu telah menciptakan suatu dunia tersendiri, yang mungkin berisi pesan atau gambaran suasana-suasana tertentu, baik fisik maupun batiniah. ${ }^{3}$ Puisi dapat membuat pembaca ke dalam ilusi tentang keindahan, terbawa dalam suatu anganangan, selain dengan keindahan penataan unsur bunyi, penciptaan gagasan, maupun suasana tertentu sewaktu membaca suatu puisi. Untuk mengatasi persoalan di atas, penelitian tindakan kelas ini menggunakan model .Model penulisan puisi ini pada

3 Jabrohim, Cara Menulis Kreatif (Yogyakarta: Pustaka Pelajar. 2001) h.67 - 68 
hakikatnya hasil modifikasi dari formula Koch yang menggunakan pendekatan proses dan teori Waluyo tentang struktur puisi yang mengacu pendapat Richards. Secara etimologis, puisi berasal dari poesis (bahasa Yunani), yaitu penciptaan atau penataan.Dalam bahasa Inggris, puisi disebut poetry, -poet, dan -poem.Mengenai kata poet, Coulter menjelaskan bahwa kata poet berasal dari Yunani yang berarti membuat atau mencipta.Dalam bahasa Belanda, istilah puisi berasal dari poizie, yang berarti sajak. ${ }^{4}$

Hasilnya diperoleh kegiatan menulis puisi melalui tahapan Rencanakan, Matangkan, Tulis, Sunting, Dan Publikasi . Model ini merupakan suatu cara membuat puisi secara terstruktur melalui modifikasi cara kerja Korch. Model ini dapat juga disebut sebagai model formula struktur. Harapannya, siswa mampu memahami dan mengerti isi materi ajar mata pelajaran Al-Qur'an Hadits yang dibentuk dalam model puisi sederhana dengan cara mudah.

Cara kerja formula Koch dilakukan melalui enam langkah. Keenam langkah tersebut adalah (1) siswa menentukan objek atau ditentukan objeknya oleh guru, (2) siswa memberi perspektif unik dan bermakna terhadap ide dan objek, (3) siswa menentukan tema, (4) siswa mengembangkan tema dengan jaring-jaring pemahaman, (5) siswa menggunakan beberapa formula

\footnotetext{
${ }^{4}$ H.G. Tarigan. Prinsip-prinsip Dast
(Bandung: Angkasa Raya. 1986) h.59

5Suroso.Classroom Action Research:

Peningkatan Kemampuan Menulis Melalui Penelitian
}

kata untuk membantu menuangkan perspektif dan ide yang ingin dikembangkan, meliputi formula penangkapan indera, formula warna, formula pengandaian, dan formula harapan, dan (6) siswa meminta teman lain untuk memberikan sumbangan katakata jika dalam proses penulisan siswa mengalami kemacetan.

Hasil integrasi cara kerja formula Korch dan teori struktur puisi Waluyo adalah tahapan menulis isi materi ajar mata pelajaran Al Qur'an Haditsdalam bentuk puisi secara . Formula ini memiliki empat tahap. Keempat tahap ini adalah (1) baca dan menyimak, (2) tentukan inti wacana dan kembangkan, (3) tulis dan koreksi, dan (4) sunting dan publikasi.

\section{Metode Penelitian}

Pendekatan yang digunakan dalam penelitian ini adalah jenis penelitian tindakan kelas (PTK) atau Classroom Action research (CAR). Hal ini karena tindakan dilakukan melalui perlakuan siklus pembelajaran khusus, yaitu mulai dari perencanaan, pelaksanaan, pengamatan, dan refleksi. Persoalan ini dapat diselesaikan dengan melakukan tindakan tertentu pada tiap sikulus sebagai langkah perbaikan atau praktik kegiatan pembelajaran di kelas secara lebih profesional. ${ }^{5}$

Salah satu karakter PTK adalah adanya persoalan dalam pembelajaran

Tindakan Kelas. (Yogyakarta: Pararaton Publishing. 2007), h.20. 
dalam pembelajaran mata pelajaran AlQur'an Hadits berdasarkan kajian bahwa telah terjadi proses kebiasaan pada diri anak adanya sikap malas terutama membaca materi ajar sebelum dan sesudah diajarkan yang berdampak pada kurangnya kemampuan siswa dalam pengetahuan Al Qur'an Hadits. Hal yang sangat risten memberi dampak yang kurang baik bagi pendidikan anak adalah persoalan anak yang tidak mau membaca. Keterpurukan anak yang tidak mau membaca, jelas berimplikasi pada kebodohan anak sebagai akibat tidak mengetahui informasi atas ilmu pengetahuan yang seharusnya didapat oleh anak.Persoalan ini ditemukan peneliti sebagai hasil pengamatan selama peneliti bertugas dan mengajar di tempat bertugas.Persoalan ini dapat diselesaikan dengan melakukan tindakan tertentu pada tiap sikulus sebagai langkah perbaikan atau praktik kegiatan pembelajaran di kelas secara lebih profesional.6 Kumpulan data tersebut diolah secara berkelompok sesuai tujuan dan masalah yang diteliti.Proses analisis data menggunakan pendekatan kualitatif, tanpa ada perhitungan statistik ${ }^{7}$. Hasil analisis ini ditafsirkan, divalidasikan atau dilakukan pengecekan keabsahan data, dan dilaporkan secara deskripsi.

Pilihan kelas V ini bersifat alamiah (tidak dimanipulasi). Situasi kelas yang sedikit gaduh dan kadang ada kendala bocor pada atapnya disaat hujan turun.Jumlah siswa kelas V MI Bustanul Athfal Pojok berjumlah 19 anak. Waktu penelitian dilakukan pada tanggal $17 \mathrm{Juli}$ S/d 19 Agustus 2019. Peneliti menggunakan model menulis puisi dalam pembelajaran Al-Qur'an Hadits di MI Bustanul Athfal untuk menambah semangat dan motivasi peserta didik dalam menerima pelajaran.

Data penelitian terdiri atas data kuantitatif dan data kualitatif. Data kuantitatif berupa nilai siswa saat tes awal menulis puisi bersumber buku teks, nilai siswa saat menulis setelah diterapkan tindakan, dan nilai aktivitas guru dan siswa selama pelaksanaan tindakan sebagai bentuk penilaian proses. Data kualitatif berupa data hasil observasi dan wawancara tahap studi pendahuluan, catatan pengamatan aktivitas guru dan siswa selama pelaksanaan tindakan, serta data hasil wawancara dengan guru dan siswa pada setiap akhir tindakan.

Pengumpulan data dilakukan sebelum dan selama pelaksanaan tindakan. Observasi dilakukan pada tahap studi pendahuluan dan selama pelaksanaan tindakan. Wawancara dilakukan pada tahap studi pendahuluan dan pada akhir pelaksanaan tindakan. Analisis dokumen dilakukan sebelum dan setelah pelaksanaan tindakan pembelajaran menulis puisi melalui model .Dan analisis dokumen setelah

\footnotetext{
'Suroso.Classroom Action Research: Peningkatan Kemampuan Menulis Melalui Penelitian Tindakan Kelas. (Yogyakarta: Pararaton 7Iskandar.Penelitian Tindakan Kelas. (Ciputat: Gaung Persada Press. 2009), h.24 
pelaksanaan tindakan dilakukan untuk mendapatkan data penilaian hasil kemampuan siswa.

Proses analisis data dilakukan sejak awal penelitian sampai pengumpulan data selesai. Menurut Miles \& Huberman proses analisis data dalam PTK dilakukan melalui tiga tahapan, yaitu tahap reduksi data, penyajian data, serta pengambilan kesimpulan dan verifikasi. Tahap reduksi data merupakan analisis yang menajamkan untuk mengorganisasikan data, sehingga simpulannya dapat diverifikasi untuk dijadikan temuan penelitian terhadap masalah yang diteliti.Reduksi data berlangsung selama penelitian di lapangan sampai pelaporan penelitian selesai. Pada tahap ini, peneliti merekam seluruh data di lapangan dalam bentuk catatan lapangan, menafsirkan, dan menyeleksi masing-masing data yang relevan dengan fokus masalah yang diteliti. Kemudian dilanjutkan dengan meringkas, mengkode, dan menemukan tema. ${ }^{8}$

Moleong menyatakan bahwa pemeriksaan keabsahan data dalam penelitian ini dilakukan dengan tiga cara, yaitu ketekunan pengamatan, triangulasi, dan pemeriksaan teman sejawat. Berikut ini penjelasan ketiga cara dalam pengecekan keabsahan data. ${ }^{9}$

8 Mattaw B. Milles and A. Micheal Huberman.1994 .An Expanded Sourcebook Qualitative Data Analisys, London Sage Publication.

${ }^{9}$ L.J.Moleong, Metodologi Penelitian

Kualittaif.(Bandung: OT Remaja Rosdakarya.

2007), h.329 - 332

\section{Hasil Penelitian dan Pembahasan}

Ide model pembelajaran realistik dikemukakan oleh Hans Freudenthal dari Belanda. Sejatinya, awal kemunculan karena adanya perkembangan matematika modern di Amerika dan praktik pembelajaran matematika yang terlalu mekanistik di Belanda. Pembelajaran yang dimaksud adalah guru memberi siswa suatu rumus lalu memberi contoh cara menggunakan rumus untuk menyelesaikan soal diikuti dengan memberi soal latihan sebanyakbanyaknya tentang penggunaan rumus tersebut. Untuk pengembangan dan penerapan guru memberi soal cerita yang dapat diselesaikan dengan rumus tadi. Pada era 1980 terjadi perubahan dasar teori belajar pada pembelajaran matematika yaitu dari behaviorisme ke arah konstruktivisme realistik.

Dalam sejarah perkembangannya, metode ini pun diadopsi pada mata pelajaran lain, meskipun hanya pada materi-materi tertentu. Hal ini disebabkan, kemampuan metode ini untuk menumbuhkan sikap kritis dalam berpikir. puan berpikir kreatif siswa dapat dikembangkan dengan pendekatan metode realistik karena adanya prinsip dan karakteristik yang diterapkan dalam pembelajaran tersebut. ${ }^{10}$ Misalnya, salah satu prinsipnya yaitu prinsip aktivitas yang menganggap perlunya penemuan

10 Siswono, Tatag Yuli Eko. Penjenjangan Kemampuan Berpikir Kreatif dan Identifikasi Tahap Berpikir KreatifSisvva dalam Memecahkan dan Mengajukan Masalah Matematika, 2007. Ringkasan disertasi diunduh dari http://suaraguru.wordpress.com [23 Desember 2019) 
kembali suatu konsep dalam mata pelajaran tersebut. Prinsip inilah mendorong siswa untuk berkreasi.

Dalam konteks ini, pusi menjadi sangat tepat untuk diterapkan menjadi model pembejaran. Puisi adalah bentuk kesusastraan yang paling tua. Tradisi berpuisi sudah merupakan tradisi kuno dalam masyarakat. Puisi juga memiliki bahasa memiliki bahasa multidimensional, artinya mampu menembus alam pikiran, perasaan, dan imajinasi manusia. Istilah puisi dalam bahasa Yunani poiseis yang berarti penciptaan. Dalam bahasa Inggris kata puisi ini adalah poetry. Thomas Carlye menyatakan bahwa puisi merupakan ungkapan pikiran yang bersifat musikal, hal yang diungkapkan dalam puisi adalah kebenaran. ${ }^{11}$ Suliana mengemukakan bahwa puisi adalah buah pikiran, perasaan dan pengalaman penyair yang diekspresikan dengan media bahasa yang khas dan unik. Sedangkan Waluyo menyatakan bahwa Puisi adalah bentuk karya sastra yang mengungkapkan pikiran dan perasaan penyair secara imajinatif dan disusun dengan mengkonsentrasikan semua kekuatan bahasa dengan pengkonsentrasian struktur fisik dan struktur batinnya. ${ }^{12}$

Menulis puisi adalah suatu keterampilan berbahasa dalam menuangkan ide, gagasan, pikirannya dalam bentuk bahasa tulis dengan memperhatikan keterikatan pada unsurunsur puisi. Saat seseorang menulis puisi, berarti seseorang tersebut akan menghasilkan suatu karya tulis berupa puisi untuk mengekspresikan perasaan dan pikirannya sehingga dapat membangkitkan imajinasi pembacanya.

Menulis puisi merupakan kegiatan aktif dan produktif. Dikatakan aktif karena dalam menulis puisi seseorang telah melakukan proses berpikir, sedangkan dikatakan produktif karena seseorang dalam menulis puisi akan menghasilkan sebuah tulisan yang dapat dinikmati oleh orang lain. Dengan menulis puisi seseorang dapat menuangkan ide, gagasan, pengetahuan, Perasaan, dan pengalaman yang terjadi pada hidupnya ke dalam bahasa tulis. Menulis puisi perlu ditanamkan kepada siswa sekolah menengah pertama, sehingga mereka memunyai kemampuan untuk mengapresiasikan puisi dengan baik.

Mengapresiasikan sebuah puisi bukan hanya ditujukan untuk penghayatan dan pemahaman puisi, melainkan dapat mempertajam kepekaan perasaan dan penalaran siswa terhadap kemanusian.

Berdasarkan penelitian yang telah dilakukan, guru mampu melaksanakan pembelajaran sesuai skenario. Siswa tampak begitu antusias ketika guru mengenalkan model realistik dan media
11 Aminuddin.Apresiasi Karya Sastra. (Bandung: CV Sinar Baru bekerjasama dengan Yayasan Asah Asih Asuh. 1987) h.80

12 Siswono, Tatag Yuli Eko. Penjenjangan Kemampuan Berpikir Kreatif dan Identifikasi
Tahap Berpikir KreatifSisvva dalam Memecahkan dan Mengajukan Masalah Matematika, 2007. Ringkasan disertasi diunduh dari http://suaraguru.wordpress.com [23 Desember 2019 
puisi. Siswa cepat memahami penjelasan guru tentang prosedur permainan susun kata. Siswa melaksanakan permainan dengan tertib dan begitu bersemangat. Dalam penelitian ini pengukuran peningkatan prestasi dapat dilihat berdasarkan hasil belajar siswa melalui tes.

\section{Paparan Tindakan Siklus I}

Berdasarkan hasil temuan dan analisis terhadap data yang ditemukan pada tahap studi pendahuluan, peneliti menyusun perencanaan tindakan yang akan dilaksanakan dalam kegiatan pembelajaran menulis puisi dengan . Rencana ini terdiri atas empat, yaitu (1) penetapan jadwal pelaksanaan tindakan, (2) penyusunan rencana pelaksanaan pembelajaran, (3) penyusunan evaluasi pembelajaran, dan (4) persiapan instrumen data. Berikut ini penjelasan tahapan perencanaan tersebut. Nilai hasil ini diperoleh dari 19 siswa. Guru mendapatkan 19 nilai proses, tetapi mendapatkan 18 nilai hasil. Artinya puisi yang dibuat siswa berjumlah 18 dan ada 1 siswa yang tidak mengumpulkan karya puisinya atau tidak selesai.

Jadi, siswa ini mengikuti kegiatan belajar, tetapi mengumpulkan karya puisi dan belum selesai. Nilai tertinggi adalah 84 yang diperoleh RZ. dan nilai terendah adalah 56 yang diperoleh ALX.Rata-rata nilai proses ini adalah 69,68 .

Pada kegiatan ini peneliti mengamati dan mencatat pelaksanaan tindakan yang dilakukan dari awal sampai akhir selama pembelajaran berlangsung. Pengamatan dilakukan sejak tahap perencanaan hingga pelaksanaan tindakan. Hal yang perlu dicatat adalah dampak dari proses dan hasil pembelajaran yang dilakukan.

Keberhasilan pembelajaran tampak jika nilai rata-rata siswa sudah memenuhi Standar Ketuntasan Belajar Minimal (SKBM) MI Bustanul Athfal Pojok untuk bidang studi Al-Qur'an Hadits adalah 70. Keberhasilan pembelajaran dapat dilihat berdasakan nilai proses dan hasil. Berdasarkan nilai ratarata penilaian yaitu 69,68. dapat dikatakan bahwa proses pembelajaran belum memenuhi SKBM. Hal ini berarti proses pembelajaran belum berhasil.. Secara keseluruhan, kegiatan pembelajaran, baik proses maupun hasil, pada siklus 1 dapat dinyatakan belum berhasil. Dengan demikian, masih diperlukan siklus 2.

\section{Paparan Tindakan Siklus II}

Berdasarkan hasil temuan siklus 1, peneliti menyusun perencanaan tindakan yang akan dilaksanakan dalam kegiatan pembelajaran menulis puisi bersumber tema mata pelajaran Al-Qur'an Hadits pada siklus 2. Secara umum, perencanaan ini sama halnya pada siklus 1 . Rencana ini terdiri atas (1) penetapan jadwal pelaksanaan tindakan, (2) penyusunan rencana pelaksanaan pembelajaran, (3) penyusunan evaluasi pembelajaran, dan (4) persiapan instrumen data. Yang membuat berbeda adalah adanya aplikasi dari catatan siklus 1. Berikut ini penjelasan keempatnya.

Nilai proses ini diperoleh 19 siswa.Nilai tertinggi adalah 85 yang diperoleh RZ.. dan nilai terendah adalah 
60 yang diperoleh Alex Afandi. Rata-rata nilai proses adalah 7 . Sebagaimana siklus 1 , kegiatan pengamatan pada siklus 2 ini dibutuhkan peneliti untuk mengamati dan mencatat pelaksanaan tindakan yang dilakukan dari awal sampai akhir selama pembelajaran Al-Qur'an Hadits metode struktur puisi berlangsung. Pengamatan dilakukan sejak tahap perencanaan hingga pelaksanaan tindakan. Hal yang perlu dicatat adalah dampak dari proses dan hasil pembelajaran yang dilakukan.

Keberhasilan pembelajaran, baik proses maupun hasil, tampak jika nilai rata-rata siswa sudah memenuhi Standar Ketuntasan Belajar Minimal (SKBM)MI Bustanul Athfal Pojok untuk bidang studi Al-Qur'an Hadits adalah 70. Keberhasilan pembelajaran dapat dilihat berdasakan nilai proses dan hasil. Berdasarkan nilai rata-rata yaitu 74,79. dapat dikatakan bahwa hasil pembelajaran sudah memenuhi SKBM. Hal ini berarti proses pembelajaran sudah mencapai SKBM.

Tabel I. Hasil Nilai Siklus

\begin{tabular}{|c|l|c|c|c|}
\hline \multirow{2}{*}{$\begin{array}{c}\text { N } \\
\mathrm{o}\end{array}$} & Siklus & \multicolumn{2}{|c|}{ Pertemuan } & \multirow{2}{*}{$\begin{array}{c}\text { Nilai } \\
\text { Rata- } \\
\text { rata }\end{array}$} \\
\hline 1 & Siklus I & 67,86 & 71,49 & 69,68 \\
\hline 2 & Siklus II & 74,59 & 74,99 & 74,79 \\
\hline
\end{tabular}

\section{Analisis}

Hasil tindakan siklus 2 menampakkan hasil yang lebih baik dari siklus 1. Perubahan tindakan jam pelajaran dari setelah pelajaran olah raga menjadi sebelum pelajaran olah raga mendapatkan hasil yang lebih baik. Selain itu, penyederhanaan istilah mempermudah siswa dalam mengisi . Perbaikan hasil belajar ini ditunjukkan dari nilai yang memenuhi SKBM.

Di siklus pertama keberhasilan pembelajaran ditinjau dari proses dan hasil dapat diukur. Ada 8 dari 19 siswa yang memenuhi. Hal ini berarti ada 11 siswa belum memenuhi kriteria ketuntasan yang sudah ditetapkan. Dari refleksi proses pembelajaran, ditemukan bahwa situasi pembelajaran kurang kondusif. Kurang kondusifnya situasi pembelajaran ini disebabkan kegiatan pembelajaran dilakukan setelah siswa mengikuti pelajaran olah raga.

Di siklus kedua ditemukan 18 dari 19 siswa yang memenuhi. Hal ini berarti ada 1 siswa belum memenuhi kriteria ketuntasan yang sudah ditetapkan. Ditemukan bahwa situasi anak didik dalam pembelajaran kurang kondusif berkaitan dengan sisi anak yang kurang mampu dalam membaca dan menulis.Maka dengan itu siklus ini dianggap berhasil meningkatkan nilai dan menambah semangat belajar peserta didik.

\section{Kesimpulan}

Dengan media puisi peserta didik menjadi memiliki suatu pengalaman belajar yang berbeda, mereka menjadi lebih terampil dan kreatif. Peserta didik mampu menulis puisi dengan baik. Peserta didik cenderung lebih cepat menangkap materi bila menggunakan sebuah media seperti puisi. Pada awalnya anak - anak merasa bahwa pelajaran AlQur'an Hadits adalah pelajaran yang membosankan, tetapi setelah memakai 
media puisi anak-anak menjadi lebih semangat lagi.

Peserta didik juga semakin semangat dalam belajar serta memahami sebuah puisi, mulai cara menulis hingga cara mempublikasikannya. Dan anggapan menulis puisi itu sulit menjadi lebih mudah. Dapat dilihat dari perkembangan nilai dari siklus I kesiklus II menunjukkan bahwa terjadi sebuah peningkatan nilai yang signifikan terhadap anak-anak. Dan Strategi ini begitu mudah dijalankan dan tidak memerlukan sebuah biaya yang mahal untuk melaksanakan demi mendapatkan nilai yang memuaskan.Anak-anak menjadi lebih aktif membaca buku untuk mendapatkan bahan puisi yang mereka inginkan.Dengan pembelajaran yang menyenangkan membawa dampak semakin mudahnya anak menerima dan memahami materi yang disampaikan oleh guru. Dalam publikasi anak-anak berlomba-lomba membuat sebuah karya yang paling baik.

\section{Daftar Pustaka}

Aminuddin. Apresiasi Karya Sastra. Bandung: CV Sinar Baru bekerjasama dengan Yayasan Asah Asih Asuh, 1987

BSNP Kemdiknas. Model Silabus dan Rencana Pelaksanaan Pembelajaran Mata Pelajaran Bahasa Indonesia SD/MI. Jakarta: Kemdiknas. 2010

Gebhardt. R, D. Rodrigues. Writing: Processes and Intention. Lexington:
H.G.Tarigan. Prinsip-prinsip Dasar Sastra. Bandung: Angkasa Raya. 1986

Iskandar. Penelitian Tindakan Kelas. Ciputat: Gaung Persada Press. 2009

Jabrohim, Cara Menulis Kreatif Yogyakarta: Pustaka Pelajar. 2001

Milles. Mattaw B. and A. Micheal Huberman.1994 .An Expanded Sourcebook Qualitative Data Analisys, London Sage Publication.

Moleong, L.J. Metodologi Penelitian Kualittaif. Bandung: OT Remaja Rosdakarya. 2007

Suroso. Classroom Action Research: Peningkatan Kemampuan Menulis Melalui Penelitian Tindakan Kelas. Yogyakarta: Pararaton Publishing. 2007 